\title{
Phillips Curve: An Empirical Research on Romania
}

\author{
Cristina Gabriela ZAMFIR ${ }^{\star}$, Corina SBUGHEA ${ }^{\star \star}$
}

\begin{tabular}{l}
\hline \multicolumn{1}{c}{ A R T I C L E I N F O } \\
\hline Article history: \\
Accepted August 2020 \\
Available online August 2020 \\
\hline JEL Classification \\
C12, C22, C52, E52 \\
Keywords: \\
Phillips curve, Inflation, \\
Unemployment, Nonlinearity
\end{tabular}

\author{
A B S T R A C T \\ This paper analyses the Phillips curve for Romania, eventually choosing the optimal type of \\ model, while also analysing the implications on monetary policy. In order to create, test and \\ analyse the Phillips curve, we utilised a backward-looking model. For empirical analysis we \\ used the annual data obtained from the National Institute of Statistics for a period between \\ 1991 and 2018.
}

(C) 2020 EAI. All rights reserved.

\section{Introduction}

Inflation and unemployment are two macroeconomic factors that have been studied over the years by many economists, who followed the connection that exists between them. The analysis of the relationship between the two macroeconomic factors began in 1958, when William Phillips wrote "The Relation between Unemployment and the Rate of Change of Money Wage Rates in the United Kingdom, 1861-1957". The study conducted by W. Phillips led to the definition of the "Phillips curve", which shows the relationship between inflation and unemployment.

Throughout history, due to the large fluctuations of the two factors, economists have altered the idea formulated by W. Phillips, considering that the relationship between the unemployment rate and the inflation rate is no longer an inverse relationship, but a compensation between the two (Friedman, 1968). Based on M. Friedman's arguments, it was concluded that the Phillips curve should be analysed over two different time periods. Thus, there appeared the "short-term" Phillips curve, which looks like a normal one, and the "longterm" Phillips curve, in which only one unemployment rate is taken into account, which is consistent with a constant rate of inflation (Phelps, 2006).

\section{Literature review}

The unemployment rate is the ratio, expressed as a percentage, between the total number of unemployed people and the active population. Inflation can be defined as the decrease in the purchasing power of a monetary unit. Any economy faces this phenomenon over time, which can only be influenced, but not fully controlled. The two macroeconomic indicators are extremely important for any national economy, hence the interest of policy makers in regulating their levels.

The Phillips curve represents, in the literature, the inverse relationship between the inflation rate and the unemployment rate. Thus, in his approach, Phillips noticed that, during periods when the unemployment rate was high, salaries stagnated or increased slowly, and during periods of low unemployment, salaries increased rapidly. The logical explanation stems from the fact that, at a low unemployment rate and, consequently, at a low supply on the labour market, employers are forced to increase salaries in order to cover labour demand.

Although Phillips initially examined the relationship between salary inflation and unemployment, most subsequent studies have focused on the general level of inflation, since high salaries are automatically reflected in the market prices of goods and services.

The inverse influence between unemployment and inflation was explained in the 1960s by a chain of reactions, starting from an expansionary fiscal policy. Thus, an increase in aggregate demand leads to an increase in labour demand, which will lead to a decrease in the number of unemployed people. In order to attract workforce, employers are forced to increase salaries, and the increase in salary costs will ultimately be reflected in price levels.

At the same time, the American economists Paul Samuelson and Robert Solow determined the same negative correlation between the two indicators in the USA (1960 "Analytics of Anti-Inflation Policy" in the

\footnotetext{
*, ${ }^{\star \star}$ Dunarea de Jos University of Galati, Romania. E-mail addresses: cristinagabrielazamfir@yahoo.com (C. G. Zamfir), sbughea@yahoo.com (C. Sbughea - Corresponding author)
} 
American Economic Review). They are the ones who proclaim the "Phillips curve" as a regulatory tool for decision-makers in politics, and not Phillips. This is exactly what happened in the following years, the relationship between the two indicators being used by decision-makers in politics to achieve the desired levels of inflation.

However, the stability of the pattern was interrupted in the 1970s, and economists Friedman and Phelps discovered that there were several short-term Phillips curves and one long-term Phillips curve for the natural unemployment rate (NUR). Thus, in his work "The Role of Monetary Policy", Freidman shows that, in the long run, unemployment cannot be reduced by increasing inflation, through an expansionary monetary policy, because the money supply is a nominal variable, which cannot influence a real variable such as unemployment. Those who set prices and salaries consider only salaries and relative prices, i.e. real levels of these variables, influenced by inflation expectations.

The long-term relationship between inflation and unemployment is illustrated by The FriedmanPhelps Phillips Curve, which highlights the existence of a level of unemployment corresponding to the concept of price stability (NUR). Thus, in the short term, the unemployment rate may fall below the NUR, putting pressure on salaries/prices, or it may increase, leading to a reduction in inflation, but over time it will tend to what Friedman calls the "Natural Rate of Unemployment" or Phelps' long-run equilibrium rate of unemployment.

Friedman's model, was, in its turn, criticized. He considered that employees make decisions according to an expected level of prices, which is adjusted only late, as compared to the actual level. During the development period, employers increase salaries to attract workforce, but prices also increase, which actually leads to a decrease in real salaries, by decreasing the purchasing power. However, employees pay attention only to the nominal level of the salary, confusing it with the real salary. In his 1968 paper, Phelps considers that not only employees are deceived, but also employers. Together they enjoy the increase in prices in their field and the increase in production, in fact ignoring the other price increases in the economy. In such periods there is a type of unemployment determined by leaving the job, in search of a better salary. Given that all employers increase salaries, this type of unemployment has not been recorded. Therefore, in the short term, the inverse correlation between unemployment and inflation was checked, but only as long as price expectations were erroneous. Critics of the two models believe that both employees and employers have learned to shape their expectations correctly, since in all past periods, characterized by an increase in production and a decline in unemployment, there has also been an increase in inflation. (Gordon, R.J., 2018)

Some authors, including Robert Lucas, Thomas Sargent, and Neil Wallace, have denied the relationship described by the Phillips curve, some even considering it as being unproductive research. The statistical data from the 1970 s, which revealed a positive correlation of the two macroeconomic indicators, supported this criticism.

\section{Methodology}

\subsection{Statistical tests}

Statistical tests are used in order to formulate statistical inferences, using the data series given by the selected population. The foundation of the statistical tests is the formulation of the two statistical hypotheses: the null hypothesis, which must not be rejected and the alternative hypothesis, which may indicate certain problems of the data series. Among the most important statistical indicators that should be analysed are: primary indicators: mean, median, minimum and maximum data series, indicators of variation and asymmetry: standard deviation, asymmetry index, excess or flattening, the Jarque-Bera test to verify the normal residue distribution.

Table 3. Descriptive statistics of the inflation rate and of the unemployment rate
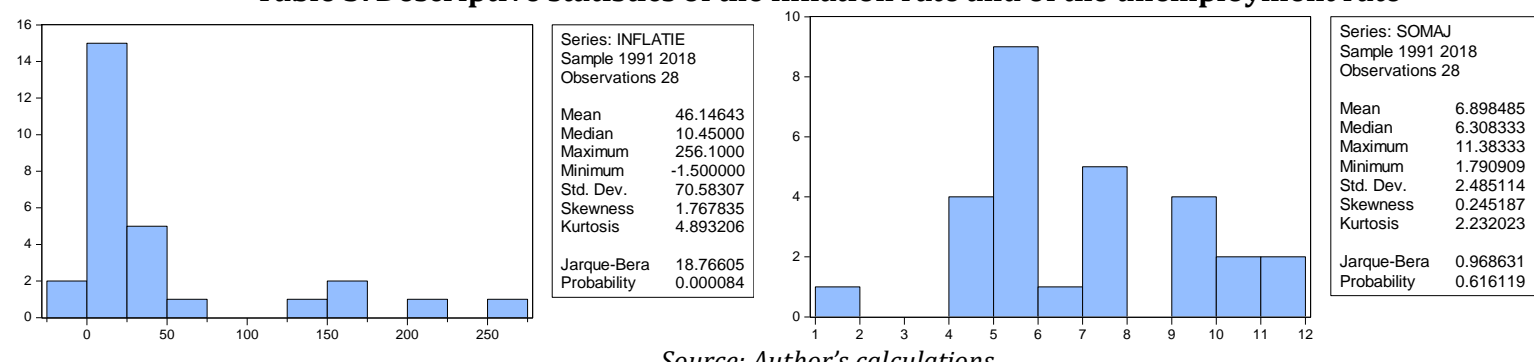

Source: Author's calculations

After analysing the information provided by descriptive statistics, we may assert that inflation had an average evolution of $46.14 \%$ in the period 1991-2018, being in the range of $-1.5 \%$ (recorded in 2016), and $256.1 \%$ (recorded in 1993), while unemployment had an average value of $6.89 \%$, in a range of $1.79 \%$ (1991) and $11.38 \%$ (1999). One may also notice that both inflation and the unemployment rate had a deviation from the average of $70.58 \%$, in the case of the inflation rate and of $2.49 \%$ in the case of the unemployment rate. 
The Pearson asymmetry coefficient for the inflation rate data series is 0.66 and shows that there is a positive asymmetry, i.e. low values are prevalent. For the unemployment rate data series, the Pearson asymmetry coefficient is 0.65 , which indicates a prevalence of lower values. The same information is provided by the Fisher asymmetry coefficient.

The Jarque-Berra test shows the normal distribution of errors and formulates two hypotheses: the null hypothesis in which the residues have a normal distribution and the alternative hypothesis in which the residues do not have a normal distribution. After analysing the data provided by the statistical test, we can conclude that in the case of inflation we do not have a normal distribution, because the probability associated with JB statistics is lower than the significance level $(\alpha=5 \%)$, while the unemployment rate series has a normal distribution.

\subsection{Models}

To analyse the relationship between the inflation rate and the unemployment rate we will use different multifactorial models, all starting from the shape of the Phillips curve. We used the standard Phillips curve with an earlier component of inflation:

where:

$$
\pi_{\mathrm{s}}=c+\sum_{i=1}^{n} a_{i} \pi_{t-i}+\sum_{i=1}^{n} b_{i} u_{t}^{t}+\varepsilon_{t}
$$

$\pi_{\mathrm{t}}$ - represents the inflation rate;

$\mathrm{u}_{\mathrm{t}}$ - represents the unemployment rate;

$\varepsilon_{\mathrm{t}}$ - represents the random variable or model error.

The method used for predicting the parameters will be the least squares method, and the choice of the "best" prediction model will be made using the Akaike coefficient.

\section{Result analysis}

The analysis was performed by using annual data for a period of 28 years, starting with 1991 until 2018. Further on, we shall present the four models we analysed, in order to finally choose the model that could best predict the relationship between the two factors.

4.1. Model 1 - analysis of the relationship between the inflation rate and the value of past inflation and the unemployment rate

The first model we shall analyse is the following:

$$
\pi_{t}=a_{1} \pi_{t-1}+b_{1} u_{t}+\varepsilon_{t}
$$

For this model, after testing all the statistical hypotheses necessary to validate the model, the following results were obtained:

Table 2. The results obtained for equation E2

Dependent Variable: INFLATION

Method: Least Squares

Sample (adjusted): 19922019

Included observations: 28 after adjustments

\begin{tabular}{lllll}
\hline \hline Variable & Coefficient & Std. Error & t-Statistic & Prob. \\
\hline \hline \multicolumn{1}{c}{ INFLATION(-1) } & 0.836332 & 0.134298 & 6.227420 & 0.0000 \\
UNEMPLOYMENT & -4.138382 & 3.997238 & -1.035310 & 0.3101 \\
\hline \hline R-squared & 0.650439 & Mean dependent var & -4.482635 \\
Adjusted R-squared & 0.636995 & S.D. dependent var & 66.64673 \\
S.E. of regression & 40.15460 & Akaike info criterion & 10.29210 \\
Sum squared resid & 41922.19 & Schwarz criterion & 10.38726 \\
Log likelihood & -142.0894 & Hannan-Quinn criter. & 10.32119 \\
Durbin-Watson stat & 1.990658 & & & \\
\hline \hline
\end{tabular}

Source: Author's calculations

Based on the information in Table 2, regarding the regression equation, we may assert the following:

- the term $\mathrm{a}_{1}$ is 0.836332 , so that at an increase in previous inflation by one unit, the current inflation would increase by 0.84 percent, with a standard error of 0.13 ; 
- the term b1 is -4.138382 , so that when the unemployment rate increases by one unit, the current inflation will decrease by 4.14 percent, with a standard error of 3.99 .

At first glance, the probability that the model is correct is about $65 \%$, this being deduced with the help of the determination coefficient (R-squared $=0.650439)$, so the model is plausible, i.e. inflation is explained in a percentage of $65 \%$ by the variables that are independent of the previous inflation rate (inflation at time $t=-$ 1) and the unemployment rate.

The Durbin-Watson statistical test, which shows the correlation between errors, is passed, because its calculated value is in the range in which the errors are independent and it is approximately 2 (Durbin, 1951).

Regarding the obtained parameters, they are also significant in predicting the equation. The significant variable is the previous inflation, because the calculated value of the t-Student test is higher than the tabulated one, which means that the previous inflation has an influence on the current inflation rate, while the unemployment rate does not have a very high influence on inflation.

The value of the Aikaike coefficient, which will be taken into account in choosing the best model that could be used in the forecast, is 10.29 .

\subsection{Model 2 - analysis of the relationship between the inflation rate and the squared unemployment rate}

The second model we shall analyse is the following:

$$
\pi_{t}=a_{1} \pi_{t-1}+b_{1} u_{t}+b_{2} u_{t}^{2}+\varepsilon_{t}
$$

For this model, after testing all the statistical hypotheses necessary to validate the model, the following results were obtained:

Table 3. The results obtained for equation $\mathrm{E} 3$

Dependent Variable: INFLATON

Method: Least Squares

Sample (adjusted): 19922019

Included observations: 28 after adjustments

\begin{tabular}{lllll}
\hline \hline Variable & Coefficient & Std. Error & t-Statistic & Prob. \\
\hline \hline INFLATON(-1) & 0.851038 & 0.134241 & 6.339629 & 0.0000 \\
UNEMPLOYMENT & 5.792084 & 3.988043 & 1.452363 & 0.1588 \\
SQUARE_UNEM. & -0.718557 & 0.487220 & -1.474812 & 0.1527 \\
\hline \hline R-squared & 0.665765 & Mean dependent var & 40.20357 \\
Adjusted R-squared & 0.639026 & S.D. dependent var & 66.64673 \\
S.E. of regression & 40.04207 & Akaike info criterion & 10.31870 \\
Sum squared resid & 40084.19 & Schwarz criterion & 10.46143 \\
Log likelihood & -141.4617 & Hannan-Quinn criter. & 10.36233 \\
Durbin-Watson stat & 2.050101 & & & \\
\hline \hline
\end{tabular}

Source: Author's calculations

Using the information provided by the least squares method it can be said that:

- the three parameters are statistically significant, and can be used in future model analysis;

- the model is approximately $67 \%$ significant and, given that the adjusted value of the determination coefficient is also close to the value of the determination coefficient, it can be said that the equation is representative for rendering of reality;

- the errors are independent, because the value of the Durbin Watson coefficient is close to 2;

- the Akaike coefficient has the value 10.32 .

4.3. Model 3 - analysis of the relationship between the inflation rate and the previous values of the inflation rate and the unemployment rate

The third model we shall analyse is the following:

$$
\pi_{t}=a_{1} \pi_{t-1}+a_{2} \pi_{t-2}+b_{1} u_{t}+\varepsilon_{t}
$$

For this model, after testing all the statistical hypotheses necessary to validate the model, the following results were obtained: 
Table 4. The results obtained for equation $\mathrm{E} 4$

Dependent Variable: INFLATIE

Method: Least Squares

Sample (adjusted): 19932019

Included observations: 27 after adjustments

\begin{tabular}{lllll}
\hline \hline Variable & Coefficient & Std. Error & t-Statistic & Prob. \\
\hline \hline INFLATION(-1) & 0.735584 & 0.188143 & 3.909699 & 0.0007 \\
INFLATION(-2) & -0.103440 & 0.183210 & -0.564601 & 0.5776 \\
UNEMPLOYMENT & 1.138026 & 1.475911 & 0.771067 & 0.4482 \\
\hline \hline R-squared & 0.600957 & Mean dependent var & 33.90000 \\
Adjusted R-squared & 0.567703 & S.D. dependent var & 58.79840 \\
S.E. of regression & 38.65952 & Akaike info criterion & 10.25190 \\
Sum squared resid & 35869.41 & Schwarz criterion & 10.39588 \\
Log likelihood & -135.4007 & Hannan-Quinn criter. & 10.29472 \\
Durbin-Watson stat & 2.131123 & & \\
\hline \hline
\end{tabular}

Source: Author's calculations

drawn:

Analysing the data obtained by applying the least squares method, the following conclusion can be

- at an increase by one unit of previous inflation, the inflation rate will increase by 0.74 percent, while an increase by one unit of inflation from two years ago will cause a decrease of 0.10 percent of current inflation. An increase in unemployment will lead to an increase in inflation by 1.16 percent;

- the model is significant in a percentage of almost $60 \%$ and the parameters are significant;

- the errors are independent, this being demonstrated by the Durbin Watson coefficient;

- the Akaike coefficient has the value 10.25 .

4.4. Model 4 - analysis of the relationship between the inflation rate and the previous values of the inflation rate and the squared unemployment rate

The fourth model we shall analyse is the following:

$$
\pi_{t}=a_{1} \pi_{t-1}+a_{2} \pi_{t-2}+b_{1} u_{t}+b_{2} u_{t}^{2}+\varepsilon_{t}
$$

For this model, after testing all the statistical hypotheses necessary to validate the model, the following results were obtained:

Table 5. The results obtained for equation E5

Dependent Variable: INFLATION

Method: Least Squares

Sample (adjusted): 19932019

Included observations: 27 after adjustments

\begin{tabular}{lllll}
\hline \hline Variable & Coefficient & Std. Error & t-Statistic & Prob. \\
\hline \hline RI & 0.752212 & 0.193820 & 3.880987 & 0.0008 \\
R_I & -0.066565 & 0.199454 & -0.333738 & 0.7416 \\
UNEMPLOYMENT & 3.175906 & 4.241309 & 0.748803 & 0.4616 \\
UNEMPLOYM.D & -0.288146 & 0.560992 & -0.513637 & 0.6124 \\
\hline \hline R-squared & 0.605482 & Mean dependent var & 33.90000 \\
Adjusted R-squared & 0.554023 & S.D. dependent var & 58.79840 \\
S.E. of regression & 39.26644 & Akaike info criterion & 10.31457 \\
Sum squared resid & 35462.63 & Schwarz criterion & 10.50655 \\
Log likelihood & -135.2467 & Hannan-Quinn criter. & 10.37166 \\
Durbin-Watson stat & 2.130992 & & & \\
\hline \hline
\end{tabular}

Source: Author's calculations 
After verifying the statistical hypotheses and fulfilling them, the last model presented can be accepted in a percentage of $61 \%$, and all the predicted parameters are significant. The Akakike coefficient has the value 10.31 .

After verifying the four models proposed by us, we will centralize the data in order to choose the model that would best present the relationship between the current inflation rate and the previous inflation and unemployment, using the Phillips curve.

Table 6. Centralization of results for the four equations

\begin{tabular}{|c|c|c|c|c|}
\hline Equation & Equation 1 & Equation 2 & Equation 3 & Equation 4 \\
\hline $\begin{array}{c}\text { Coefficient of } \\
\text { determination }\end{array}$ & $65.04 \%$ & $66.57 \%$ & $60.09 \%$ & $60.54 \%$ \\
\hline $\begin{array}{c}\text { The Akaike } \\
\text { coefficient }\end{array}$ & 10.29 & 10.31 & 10.25 & 10.31 \\
\hline
\end{tabular}

By analysing table 6, we notice that all the predicted models have a probability of acceptance of over $60 \%$, but by analysing the Akaike coefficient, its lowest value is that of the E3 equation, although the differences between the coefficients of the other models are not very large.

In conclusion, the equation we can use in predicting the relationship between inflation and unemployment, with the help of the Phillips curve, is equation E3, of the form:

$$
\pi_{t}=a_{1} \pi_{t-1}+a_{2} \pi_{t-2}+b_{1} u_{t}+\varepsilon_{t}
$$

\section{Conclusions}

Economists' views on the importance of the Phillips curve, expressed over time, have been divided. Although controversial, the Phillips curve continues to be an important macroeconomic tool and, in particular, the subject of many empirical studies: "The Phillips curve is the connective tissue between the Federal Reserve's dual mandate goals of maximum employment and price stability. Despite regular declarations of its demise, the Phillips curve has endured. It is useful, both as an empirical basis for forecasting and for monetary policy analysis".(Williams J.C., 2019)

Jerome H. Powell în his speech from 2018, at the 60th Annual Meeting of the National Association for Business Economics, Boston, Massachusetts had a more reserved approach: "At the risk of spoiling the surprise, I do not see it as likely that the Phillips curve is dead, or that it will soon exact revenge. What is more likely, in my view, is that many factors, including better conduct of monetary policy over the past few decades, have greatly reduced, but not eliminated, the effects that tight labor markets have on inflation."

\section{References}

1. Dobrescu M., Paicu C., Iacob S. (2011), Rata naturală a şomajului şi implicaţiile acesteia în planul politicii economice, Economie teoretică și aplicată. Volumul XVIII, No. 2(555), pp. 186-201

2. $\quad$ Durbin, J. and Watson, G. S. (1951). Testing for serial correlation in least squares regression (II). Biometrika, 38(1-2): pp. 159-179.

3. Friedman, M. (1968), The role of monetary policy', American Economic Review, Vol. 58, pp. 1-17

4. Gordon, R.J.(1997), The Time-Varying NAIRU and its Implications for Economic Policy, Journal of Economic Perspectives, vol.11, nr.1, Winter 1997, pp. 11-32

5. Gordon, R.J., (1998), Foundations of the Goldilocks Economy: Supply Shocks and the TimeVarying NAIRU, BPEA, 2

6. Gordon, R.J., (2018), Friedman and Phelps On The Phillips Curve Viewed From A Half Century's Perspective, National Bureau Of Economic Research, Working Paper 24891

7. Lucas, Robert E., Jr. (1972), “Expectations and the Neutrality of Money," Journal of Economic Theory 4 (April), pp. 103-24.

8. Lucas, Robert E., Jr. (1973), "Some International Evidence on Output-Inflation Tradeoffs," American Economic Review 63, pp. 326-34.

9. Lucas, Robert E., Jr., and Sargent, Thomas J. (1978), "After Keynesian Macroeconomics," in After the PC: Persistence of High Inflation and High Unemployment. Boston: Federal Reserve Bank of Boston, pp. 49-72.

10. Phelps, E. (1967), Phillips curve, expectation of inflation, and optimal inflation over time, Economica, Vol. 34, pp.254-281.

11. Phelps, E. (2006), Analysis of Intertemporal Tradeoffs in Macroeconomic Policy, The Royal Swedish Academy of Sciences, Stockholm, Sweden

12. Sargent, Thomas J. (1971), A Note on the 'Accelerationist' Controversy, Journal of Money, Credit, and Banking 3 (no. 3, August), pp. 721725

13. Sargent, Thomas J. and Wallace, Neil (1975), Rational Expectations, the Optimal Monetary Instrument, and the Optimal Money Supply Rule, Journal of Political Economy 83 (April), pp. 241-54

14. Powell Jerome H., 2018 - https://www.federalreserve.gov/newsevents/speech/powell20181002a.htm

15. Williams J.C., 2019 - https://www.newyorkfed.org/newsevents/speeches/2019/wil190222

16. https://www.econlib.org/library/Enc/PhillipsCurve.html

17. https://www.economicsonline.co.uk/Global_economics/Phillips_curve.html 